\title{
Voltammetric Behavior of Amfepramone (Diethylpropion) at the Hanging Mercury Drop Electrode and its Analytical Determination in Pharmaceutical Formulations
}

\author{
Leandro M. de Carvalho, ${ }^{*}$, Paulo C. do Nascimento, ${ }^{a}$ Denise Bohrer, ${ }^{a}$ Daniele Correia, ${ }^{a}$ \\ André V. de Bairros, ${ }^{b}$ Valdeci J. Pomblum ${ }^{c}$ and Solange G. Pomblum ${ }^{b}$ \\ ${ }^{a}$ Departamento de Química, Universidade Federal de Santa Maria, CP 5051, \\ 97110-970, Santa Maria-RS, Brazil \\ ${ }^{b}$ Departamento de Toxicologia e Analises Clínicas, Universidade Federal de Santa Maria, \\ 97110-970, Santa Maria-RS, Brazil
}

${ }^{c}$ Departamento de Clínica Médica, Universidade Federal de Santa Maria, CP 5061, 7110-970, Santa Maria, RS, Brazil

Este trabalho descreve um estudo sistemático do comportamento voltamétrico da anfepramona no eletrodo de mercúrio de gota pendente (HMDE) por voltametria cíclica $(\mathrm{CV})$ e voltametria de corrente alternada (AC). Os estudos mostraram o comportamento adsortivo da anfepramona no HMDE e foram realizados em soluções de $\mathrm{H}_{2} \mathrm{SO}_{4} 0,1 \mathrm{~mol} \mathrm{~L}^{-1}$ ( $\mathrm{pH} 1.0$ ) e tampão de Ringer (pH 11,0) como eletrólito suporte. A faixa linear para a determinação de anfepramona por voltametria de pulso diferencial de varredura linear (DPV) foi de 0,05 a 2,0 $\mathrm{mg} \mathrm{L}^{-1}(\mathrm{r}=$ $0,998)$ em meio ácido e de 0,25 a $4,0 \mathrm{mg} \mathrm{L}^{-1}(\mathrm{r}=0,994)$ em meio alcalino. Os desvios padrão relativos calculados para 5 medidas de anfepramona $0,5 \mathrm{mg} \mathrm{L}^{-1} \mathrm{em}$ meio ácido e meio alcalino foram de 2,5 e 4,0\%, respectivamente. Os limites de detecção calculados para a determinação de enfepramona em meio ácido e meio alcalino foram de 0,035 e $0,18 \mathrm{mg} \mathrm{L}^{-1}$, respectivamente. As metodologias foram aplicadas para a determinação de anfepramona por DPV em cápsulas e comprimidos de formulações farmacêuticas usadas no tratamento da obesidade. Os valores de recuperação entre 90,0 e 101,0\% para anfepramona adicionada a misturas sintéticas contendo femproporex, mazindol, sibutramina, fluoxetina, cafeína, diazepan e metformina provam a aplicabilidade do método para a sua determinação na presença de outras drogas normalmente adicionadas de forma ilegal a formulações farmacêuticas comercializadas como medicamentos naturais.

This paper describes a systematic study of the voltammetric behavior of amfepramone at the hanging mercury drop electrode (HMDE) by cyclic (CV) and alternating current (AC) voltammetric methods. The studies showed the adsorptive behavior of amfepramone at the HMDE and were performed in $\mathrm{H}_{2} \mathrm{SO}_{4} 0.1 \mathrm{~mol} \mathrm{~L}^{-1}(\mathrm{pH} 1.0)$ and Ringer buffer $(\mathrm{pH}$ 11.0) as supporting electrolytes. The linear range for the amfepramone determination by differential pulse voltammetry (DPV) was 0.05 to $2.0 \mathrm{mg} \mathrm{L}^{-1}(\mathrm{r}=0.998)$ in acidic medium and 0.25 to 4.0 $\mathrm{mg} \mathrm{L}^{-1}(\mathrm{r}=0.994)$ in alkaline medium. The relative standard deviation calculated was $2.5 \%$ and $4.0 \%$ for five measurements of $0.5 \mathrm{mg} \mathrm{L}^{-1}$ amfepramone in acidic and alkaline medium, respectively. The detection limits calculated for the amfepramone determination in acidic and alkaline medium were 0.035 e $0.18 \mathrm{mg} \mathrm{L}^{-1}$, respectively. The methods were applied for the determination of amfepramone by DPV in tablets and capsules of pharmaceutical formulations used in the treatment of obesity. Recoveries values ranging from 90.0 to $101.0 \%$ for amfepramone added to synthetic mixtures containing fenproporex, mazindol, sibutramine, fluoxetine, caffeine, diazepam, and metformin as interferents prove the applicability of the method for its determination in the presence of other drugs normally added illegally to pharmaceutical formulations commercialized as natural medicaments.

Keywords: amfepramone, voltammetric behavior, pharmaceutical formulations

*e-mail: leandrocarvalho@smail.ufsm.br 


\section{Introduction}

The abusive use of anorexics has grown lately, mainly because of its use in the treatment of obesity. The consumption of anorexics in Brazil is approximately 23.6 tons per year, surpassed only by Chile and Germany. ${ }^{1}$ Furthermore, herbal formulations with claimed slimming activity, which are assumed to improve the effectiveness of food diets, have been in increasing use in Brazil.

Obesity is a major risk factor for morbity and mortality ${ }^{2,3}$ and its therapeutic treatment include anorexic agents such as amfepramone (diethylpropion - Figure 1). The administration of amfepramone can tipically lead to the increase of locomotor activity, euphorie, ${ }^{4}$ nervousness, irritability, insomnia and hyperkinesis. ${ }^{5}$ It may also induce to a schizophrenia-like psychosis if it is administered at high doses or for a long time. ${ }^{6-8}$

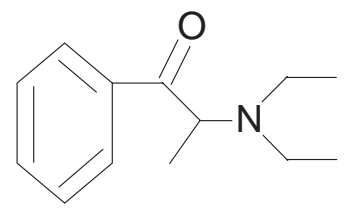

Figure 1. Structure of amfepramone (diethylpropion).

To the best of our knowledge, there is still no official method for the determination of amfepramone. However, it has been determined mainly by thin layer and liquid chromatography, ${ }^{9,10}{ }^{1} \mathrm{H}$ NMR spectroscopy ${ }^{11}$ and voltammetry. ${ }^{12}$ Some of these methods are time consuming and involve high instrumentation costs if compared to voltammetric methods. The voltammetric method published by Tan and coworkers ${ }^{12}$ describes the determination of amfepramone by linear sweep voltammetry with a detection limit of $1 \times 10^{-9} \mathrm{~mol} \mathrm{~L}^{-1}(0.21$ $\left.\mu \mathrm{g} \mathrm{L}^{-1}\right)$. However, a systematic investigation of the amfepramone determination in pharmaceutical formulations (synthetic and natural) was not yet described in the literature. In this context, the voltammetry offers the possibility for a rapid and sensitive determination of amfepramone in pharmaceutical formulations. Besides, solutions resulting from solubilization of tablets or capsules do not need to be filtered exhaustively before voltammetric determinations, which can be performed in the presence of particulate matter. ${ }^{13}$ This is a further advantage of voltammetric methods compared with either spectroscopic or liquid chromatographic procedures, where the samples must be filtered until the complete separation of the insoluble excipients.
This paper describes a systematic study of the voltammetric behavior of amfepramone at the hanging mercury drop electrode (HMDE) by cyclic (CV) and alternating current (AC) voltammetric methods. The studies showed the adsorptive behavior of amfepramone at the HMDE and were performed in two different alkaline and acidic supporting electrolytes. The voltammetric peaks obtained at $-0.78 \mathrm{~V},-1.35 \mathrm{~V}$, and $-1.70 \mathrm{~V}$ for amfepramone in acidic and alkaline medium are characterized by irreversible reduction processes, which have a contribution from both surface species adsorbed on the electrode and solution species diffusing to the electrode surface. The methods were applied for the determination of amfepramone by differential pulse voltammetry (DPV) in tablets and capsules. The method allowed the selective determination of amfepramone in pharmaceutical formulations and synthetic mixtures containing anorexics, benzodiazepines and antidepressants.

\section{Experimental}

\section{Apparatus}

The voltammetric measurements were performed using a Metrohm 693 VA Processor in combination with a 694 VA Stand (all from Metrohm, Herisau, Switzerland). The three-electrode configuration consisted of the hanging mercury drop electrode (HMDE) as working electrode, an $\mathrm{Ag} / \mathrm{AgCl}$ reference electrode $\left(3 \mathrm{~mol} \mathrm{~L}^{-1} \mathrm{KCl}\right)$ and a platinum wire as auxiliary electrode. The surface area of the HMDE was $0.6 \mathrm{~mm}^{2}$. In cyclic voltammetric (CV) measurements in alkaline medium the scans between -0.60 and $-1.8 \mathrm{~V}$ were preceded by stirred deposition (2000 rpm) at the HMDE for $120 \mathrm{~s}$ at $-0.60 \mathrm{~V}$ and different scan rates between 100 and $1000 \mathrm{mV} \mathrm{s}^{-1}$ were used. In cyclic voltammetric $(\mathrm{CV})$ measurements in acidic medium the scans between -0.45 and $-1.0 \mathrm{~V}$ were preceded by stirred deposition (2000 rpm) at the HMDE for $120 \mathrm{~s}$ at $-0.45 \mathrm{~V}$ and different scan rates between 100 and 1000 $\mathrm{mV} \mathrm{s}^{-1}$ were used. The deposition potentials used for amfepramone in $\mathrm{CV}$ measurements were based on the results obtained from alternating current (AC) voltammetric experiments, which shows the region of the amfepramone adsorption at the HMDE. In alternating current (AC) voltammetric measurements the scans between -0.40 and $-1.8 \mathrm{~V}$ in alkaline medium and between -0.40 and $-1.0 \mathrm{~V}$ in acidic medium were performed with an $\mathrm{AC}$ amplitude of $20 \mathrm{mV}$, a frequency of $60 \mathrm{~Hz}$, phase angles of $\varphi=0^{\circ}$ and $\varphi=90^{\circ}$, and a scan rate of $20 \mathrm{mV} \mathrm{s}^{-1}$. In differential pulse voltammetric (DPV) measurements the scans between -1.10 and $-1.8 \mathrm{~V}$ (alkaline medium) or between 
-0.4 and $-1.0 \mathrm{~V}$ (acidic medium) were performed with a pulse amplitude of $-50 \mathrm{mV}$, a pulse duration of $40 \mathrm{~ms}$ and a scan rate of $20 \mathrm{mV} \mathrm{s}^{-1}$.

\section{Reagents and solutions}

All chemicals used were of analytical grade purity. Water was purified by a Milli-Q Ultra Pure Water System (Millipore, Bedford, USA). Amfepramone hydrochloride $\left(99.4 \%, \mathrm{MW}=241.76 \mathrm{~g} \mathrm{~mol}^{-1}\right)$ was obtained from Medley Indústria Farmacêutica (Brazil) and it was used without further purification. Sulfuric acid (98\%), methanol, dibasic sodium phosphate $\left(\mathrm{Na}_{2} \mathrm{HPO}_{4}\right)$ and monobasic sodium phosphate $\left(\mathrm{NaH}_{2} \mathrm{PO}_{4}\right)$ were obtained from Merck (Darmstadt, Germany).

Stock solutions of amfepramone hydrochloride $0.1 \%$ $(\mathrm{m} / \mathrm{v})$ were made up in methanol. The working solutions of amfepramone hydrochloride $0.01 \%(\mathrm{~m} / \mathrm{v})$ were prepared by dilution of the stock solution in methanol. All the solutions were stored at $-17^{\circ} \mathrm{C}$ until their use.

The supporting electrolytes used in the studies were $\mathrm{H}_{2} \mathrm{SO}_{4} 0.1 \mathrm{~mol} \mathrm{~L}^{-1}$ and Ringer buffer $\mathrm{pH} 11.0\left(\mathrm{Na}_{2} \mathrm{HPO}_{4}\right.$ $0.5 \mathrm{~mol} \mathrm{~L}^{-1} / \mathrm{NaH}_{2} \mathrm{PO}_{4} 0.5 \mathrm{~mol} \mathrm{~L}^{-1}$ ) aqueous solutions.

Study of the voltammetric behavior of amfepramone by cyclic and alternating current voltammetry

For the study of the voltammetric behavior of amfepramone at the HMDE by cyclic and alternating current voltammetry, appropriate amounts of amfepramone were added to the voltammetric cell containing $10 \mathrm{~mL}$ of a $\mathrm{H}_{2} \mathrm{SO}_{4} 0.1 \mathrm{~mol} \mathrm{~L}^{-1}$ or a Ringer buffer $\mathrm{pH} 11.0$ $\left(\mathrm{Na}_{2} \mathrm{HPO}_{4} 0.5 \mathrm{~mol} \mathrm{~L}^{-1} / \mathrm{NaH}_{2} \mathrm{PO}_{4} 0.5 \mathrm{~mol} \mathrm{~L}^{-1}\right)$ aqueous solution as supporting electrolyte. The solutions were dearated for $5 \mathrm{~min}$ with nitrogen before the voltammetric measurements.

Determination of amfepramone in tablets, capsules and synthetic mixtures by differential pulse voltammetry

For the determination of amfepramone in commercial pharmaceutical formulations, the average weight of 10 tablets/capsules containing $75 \mathrm{mg}$ amfepramone hydrochloride was firstly obtained. Then five tablets/ capsules were pulverized and homogenized using a mortar and pestle. An aliquot of $100 \mathrm{mg}$ of the finely powder mixture was weighed and transferred into an Erlenmeyer containing $50 \mathrm{~mL}$ of methanol. The flask was then placed in an ultrasonic bath for $30 \mathrm{~min}$ and the extract was filtered once through cotton and diluted twice with methanol in a $50 \mathrm{~mL}$ volumetric flask. This solution extract was subsequently diluted 10 times in methanol in a volumetric flask and $100 \mu \mathrm{L}$ was added to $10 \mathrm{~mL}$ of supporting electrolyte for the voltammetric determination. The quantification was performed by the standard addition method $(n=3)$ and the formulations were analyzed at least in triplicate. DPV measurements were performed by scanning the potential from -1.0 to $-1.8 \mathrm{~V}$ (alkaline medium) and from -0.4 to $-1.0 \mathrm{~V}$ (acidic medium) with a scan rate of $20 \mathrm{mV} \mathrm{s}^{-1}$. The calculation of the final amfepramone content of each formulation was made considering the average weight obtained for 10 capsules/ tablets and the results were compared with the nominal content declared by the manufacturer $(75 \mathrm{mg})$.

For the determination of amfepramone in synthetic mixtures, $10 \mathrm{~mL}$ of supporting electrolyte was spiked with amfepramone, fenproporex, mazindol, sibutramine, fluoxetine, caffeine, diazepam, and metformin at different concentrations (from 0.1 to $2.0 \mathrm{mg} \mathrm{L}^{-1}$ ). This mixture was then treated as a sample and the quantification of anfepramone in the presence of the drugs was performed by the standard addition method $(n=3)$ at least in triplicate. DPV measurements were performed as described above.

\section{Results and Discussion}

Study of the voltammetric behavior of amfepramone at the mercury electrode by alternating current and cyclic voltammetry

The occurrence of adsorption processes at the mercury electrode has enabled the development and application of more sensitive electrochemical methods for the determination of low concentrations of pharmaceuticals. In AC voltammetric measurements, adsorption characteristics peaks can be produced at potentials where the adsorption or desorption occurs. These non-faradaic processes occur at positive or negative potentials, where an adsorbed species is displaced from the electrode by virtue of an increased affinity of the supporting electrolyte. ${ }^{14,15}$ In the potential range where the substance is adsorbed on the electrode surface, a depression in the capacity of the double layer (and, thus, in the current measured with a phase angle $\varphi=90^{\circ}$ ) is observed and this depression becomes larger with increasing concentrations up to saturation of the electrode surface. ${ }^{16,17}$

In this work, the studies performed by AC voltammetry in two different supporting electrolytes show that amfepramone is adsorbed at the HMDE in a broad potential range either in acidic or in alkaline medium. As can be seen in Figures 2 and 3, a phase-selective 
A

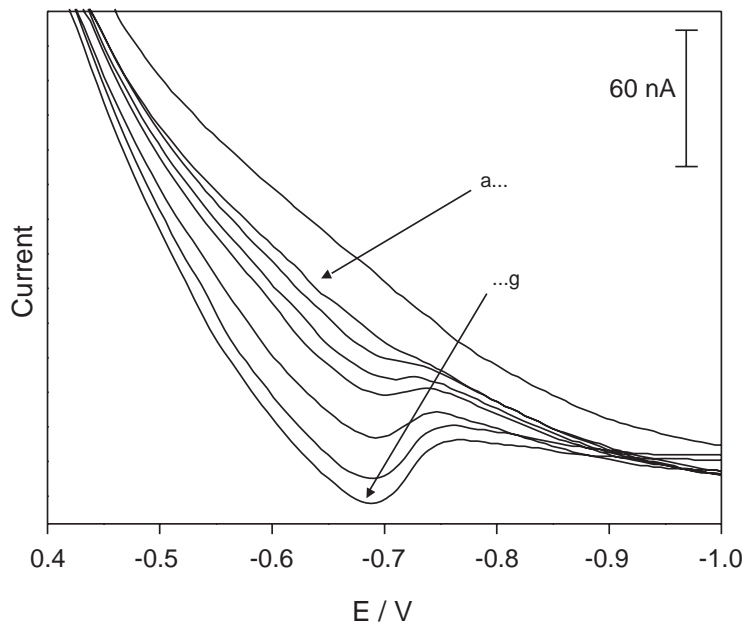

B

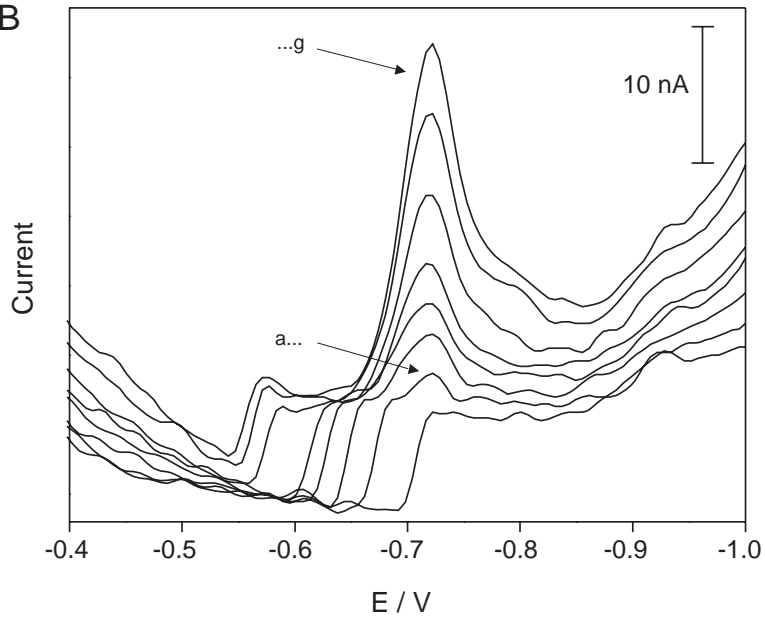

Figure 2. Alternating current voltammetric behavior of amfepramone at (A) $\varphi=90^{\circ}$ and (B) $\varphi=0^{\circ}$ using $0.1 \mathrm{~mol} \mathrm{~L}^{-1} \mathrm{H}_{2} \mathrm{SO}_{4}$ as supporting electrolyte: (a) $1 \mathrm{mg} \mathrm{L}^{-1}$ amfepramone $\left(4.13 \mu \mathrm{mol} \mathrm{L}^{-1}\right)$, (b) $2 \mathrm{mg} \mathrm{L}^{-1}$ amfepramone (8.26 $\mu \mathrm{mol} \mathrm{L}{ }^{-1}$ ), (c) $3 \mathrm{mg} \mathrm{L}^{-1}$ amfepramone $\left(12.39 \mu \mathrm{mol} \mathrm{L}^{-1}\right)$, (d) $4 \mathrm{mg} \mathrm{L}^{-1}$ amfepramone $\left(16.52 \mu \mathrm{mol} \mathrm{L}^{-1}\right)$, (e) $6 \mathrm{mg} \mathrm{L}^{-1}$ amfepramone $\left(24.78 \mu \mathrm{mol} \mathrm{L}^{-1}\right)$, (f) $8 \mathrm{mg} \mathrm{L}^{-1}$ amfepramone $\left(33.04 \mu \mathrm{mol} \mathrm{L}^{-1}\right)$, (g) $10 \mathrm{mg} \mathrm{L}^{-1}$ amfepramone $\left(41.30 \mu \mathrm{mol} \mathrm{L}^{-1}\right)$. The $\mathrm{AC}$ amplitude was $20 \mathrm{mV}$, the AC frequency was 60 $\mathrm{Hz}$ and the scan rate was $20 \mathrm{mV} \mathrm{s}^{-1}$.

voltammetric scan with phase angles $\varphi=0^{\circ}$ and $\varphi=90^{\circ}$ permit to distinguish the faradaic and capacitive processes occuring at the HMDE using both electrolyte systems. A decrease of the background current (originated by the supporting electrolyte) in the potential range from -0.40 to $-1.0 \mathrm{~V}$ in acidic medium (Figure $2 \mathrm{~A}$ ) and from -0.40 to $-1.10 \mathrm{~V}$ in alkaline medium (Figure $3 \mathrm{~A}$ ) proves the occurrence of adsorption within this potential ranges. The AC voltammograms in Figure 2B shows that amfepramone gives a reduction peak at $-0.73 \mathrm{~V}$ in acidic medium. Furthermore, the characteristic desorption peak around $-1.10 \mathrm{~V}$ obtained for anfepramone in alkaline medium (Figure 3B) appears about $0.2 \mathrm{~V}$ before its first reduction peak $(-1.35 \mathrm{~V})$ and it could be clearly observed only in phase selective AC measurements, which proves its relation with a capacitive process occurring at the HMDE.
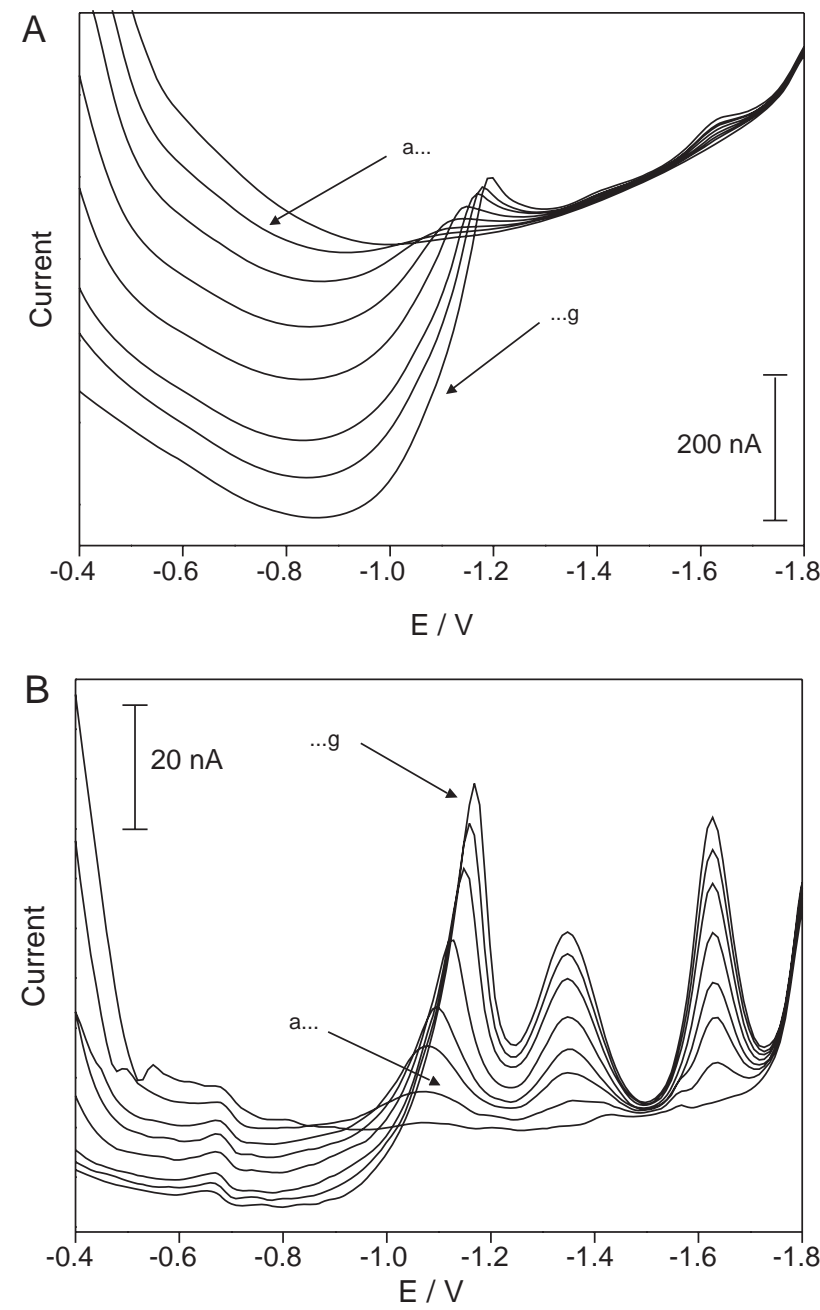

Figure 3. Alternating current voltammetric behavior of amfepramone at (A) $\varphi$ $=90^{\circ}$ and $(\mathrm{B}) \varphi=0^{\circ}$ using Ringer buffer $\mathrm{pH} 11.0\left(\mathrm{Na}_{2} \mathrm{HPO}_{4} 0.5 \mathrm{~mol} \mathrm{~L}^{-1}\right.$ $\mathrm{NaH}_{2} \mathrm{PO}_{4} 0.5 \mathrm{~mol} \mathrm{~L}^{-1}$ ) as supporting electrolyte: (a) $1 \mathrm{mg} \mathrm{L}^{-1}$ amfepramone (4.13 $\mu \mathrm{mol} \mathrm{L}^{-1}$ ), (b) $2 \mathrm{mg} \mathrm{L}^{-1}$ amfepramone $\left(8.26 \mu \mathrm{mol} \mathrm{L}^{-1}\right.$ ), (c) $3 \mathrm{mg} \mathrm{L}^{-1}$ amfepramone (12.39 $\left.\mu \mathrm{mol} \mathrm{L}^{-1}\right)$, (d) $4 \mathrm{mg} \mathrm{L}^{-1}$ amfepramone (16.52 $\mathrm{mmol} \mathrm{L}^{-1}$ ), (e) $6 \mathrm{mg} \mathrm{L}^{-1}$ amfepramone ( $24.78 \mu \mathrm{mol} \mathrm{L}^{-1}$ ), (f) $8 \mathrm{mg} \mathrm{L}^{-1}$ amfepramone (33.04 $\left.\mu \mathrm{mol} \mathrm{L}{ }^{-1}\right)$, (g) $10 \mathrm{mg} \mathrm{L}^{-1}$ amfepramone $\left(41.30 \mu \mathrm{mol} \mathrm{L}^{-1}\right)$. The AC amplitude was $20 \mathrm{mV}$, the AC frequency was $60 \mathrm{~Hz}$ and the scan rate was $20 \mathrm{mV} \mathrm{s}^{-1}$.

Therefore, it may be concluded that in alkaline medium amfepramone is not adsorbed on the HMDE at the onset for its reduction and, thus, the subsequent faradaic peaks are due to the solution species diffusing from the adjacencies to the electrode surface.

Figure 4 shows the cyclic voltammetric behavior of amfepramone at the HMDE in acidic and alkaline medium. As can be seen in Figure 4A, it behaves irreversibly at the HMDE in acidic medium $(\mathrm{pH}=1.0)$, giving a well-defined cathodic peak at $-0.78 \mathrm{~V}$. On the other hand, amfepramone presents two cathodic peaks at -1.35 and $-1.70 \mathrm{~V}$ in alkaline medium $(\mathrm{pH}=11.0)$, as shown in Figure 4B. The repetitive cyclic voltammograms shown in these Figures (4A and 4B) were obtained at a 
constant scan rate $(100 \mathrm{mV} / \mathrm{s})$ after an accumulation step of $120 \mathrm{~s}$ at the HMDE (only before the first cycle). As can be seen, the cathodic peaks at $-0.78 \mathrm{~V}$ (acidic medium), $-1.35 \mathrm{~V}$ (alkaline medium), and $-1.70 \mathrm{~V}$ (alkaline medium) decreased in the second cycle and reached a constant value in subsequent cycles, which is also an evidence of the adsorptive behavior of amfepramone at the mercury electrode surface. However, when the accumulation step of $120 \mathrm{~s}$ is used before the potential scan, the peak currents at $-0.78 \mathrm{~V},-1.35 \mathrm{~V}$, and $-1.70 \mathrm{~V}$ (Figure $4 \mathrm{~A}$ and $4 \mathrm{~B}$ ) are essentially a linear function of the square root of scan rate $\left(v^{1 / 2}\right)$ in the range from 100 to $1000 \mathrm{mV} \mathrm{s}^{-1}$, indicating that the reduction of anfepramone in both acidic and alkaline medium may be also related to a diffusion controlled process. The data obtained from the linear regression for $I_{p}(n A) v s . v^{1 / 2}\left(\mathrm{mV} \mathrm{s}^{-1}\right)$ are the following: $\mathrm{r}=0.995$ and $\mathrm{I}_{\mathrm{p}}(\mathrm{nA})=26.20 \mathrm{v}^{1 / 2}-35.78$ (acidic medium); $\mathrm{r}=0.996$ and $\mathrm{I}_{\mathrm{p}}(\mathrm{nA})=5.45 \mathrm{v}^{1 / 2}-4.08$ (alkaline medium).
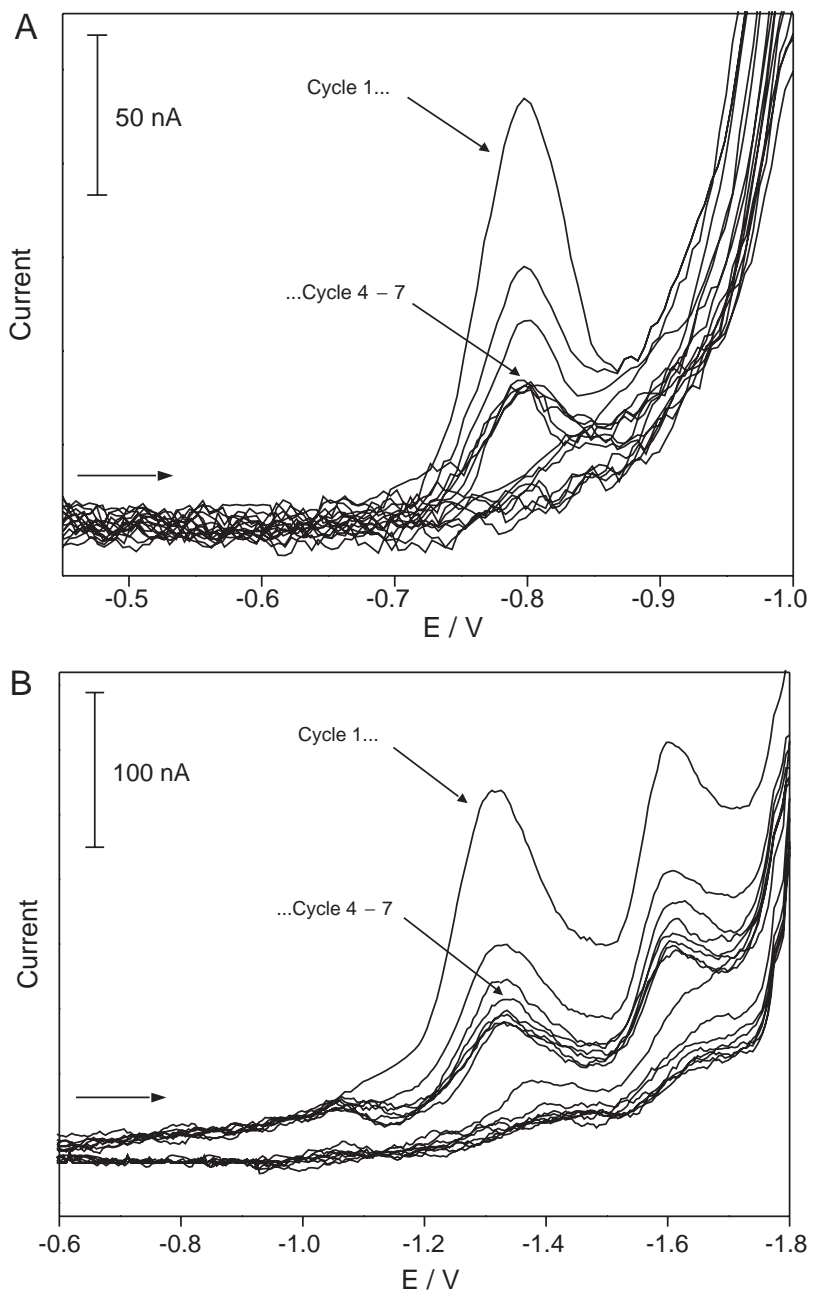

Figure 4. Cyclic voltammetric behavior of $5 \mathrm{mg} \mathrm{L}^{-1}$ amfepramone (20.65 $\mu \mathrm{mol} \mathrm{L}-1)$ in (A) acidic medium of $0.1 \mathrm{~mol} \mathrm{~L}^{-1} \mathrm{H}_{2} \mathrm{SO}_{4}(\mathrm{pH} \mathrm{1.0)}$ ) and (B) alkaline medium of Ringer buffer ( $\mathrm{pH}$ 11.0). Each scan was preceded by stirred deposition for $120 \mathrm{~s}$ at $-0.45 \mathrm{~V}(\mathrm{~A})$ and $-0.60 \mathrm{~V}(\mathrm{~B})$. The scan rate was $500 \mathrm{mV} \mathrm{s}^{-1}$ (A and B).
Furthermore, it is also possible to conclude that when an accumulation (adsorption) step is used before the potential scan, the desorption occurring at $-1.10 \mathrm{~V}$ increases the amfepramone concentration in a region of the solution adjacent to the electrode surface with respect to that in the bulk of the solution. Nevertheless, the difference between these concentrations decreases in the successive scans, and, eventually, both concentrations coincide. In relation to the behavior observed in acidic medium, amfepramone is adsorbed on the electrode when its reduction begins, and the resulting current has a contribution from both species weakly adsorbed on the electrode surface and solution species diffusing to this surface. From these results, one can conclude that the cathodic peak current obtained in the irreversible reduction of amfepramone at the HMDE either in acidic or in alkaline medium has a contribution from both surface species adsorbed on the electrode and solution species diffusing to the electrode surface.

Concerning the reaction mechanism of amfepramone at the HMDE, the faradaic process observed at $-0.78 \mathrm{~V}$ in acidic medium can be attributed to the reduction of the carbonyl group $(\mathrm{C}=\mathrm{O})$ in the amfepramone molecule, which may involve $2 \mathrm{e}^{-}$and 2 $\mathrm{H}^{+}$. This reduction mechanism seems to be similar to those already described for other pharmaceutical compounds containing similar carbonyl groups. ${ }^{18-21}$ Furthermore, this peak is strongly $\mathrm{pH}$ dependent and it shifts toward more negative potentials by increasing the $\mathrm{pH}$ value from 1.0 to $11.0(\Delta \mathrm{E} \cong 0.55 \mathrm{~V})$. From these results, one can conclude that the voltammetric peak obtained at $-1.35 \mathrm{~V}$ in alkaline medium is related to the same faradaic process that occurs at $-0.78 \mathrm{~V}$ in acidic medium. Nevertheless, a systematic study of the $\mathrm{pH}$ dependence of the amfepramone potential peaks showed that the second reduction peak at $-1.70 \mathrm{~V}$ appears only at $\mathrm{pH}$ values higher than 9.5. It means that in acidic medium this faradaic process cannot be identified because of the interference of the acidic supporting electrolyte, which imposes a cathodic limit at $-1.0 \mathrm{~V}$ for the useful potential window. However, the nature of the reduction product obtained at $-1.70 \mathrm{~V}$ could not be elucidated so far.

\section{Dynamic range and detection limit for the amfepramone determination by $D P V$}

The determination of $0.25,0.5$ and $1.0 \mathrm{mg} \mathrm{L}^{-1}$ amfepramone using previous deposition times at the HMDE ranging from 10 to $240 \mathrm{~s}$ has not caused a significant increase in the sensitivity of the method either 
in alkaline or acidic medium, what may be related to the strong adsorption of amfepramone at the HMDE leading to a rapid saturation of the electrode surface. Concerning the deposition potential, no significant enhancement in the peak current of $1.0 \mathrm{mg} \mathrm{L}^{-1}$ amfepramone was found by applying different deposition potentials in the range from 0 to $-0.6 \mathrm{~V}$ in acidic medium and from 0 to $-1.0 \mathrm{~V}$ in alkaline medium. Therefore, the determination of amfepramone under optimized conditions was made by voltammetry in the differential pulse mode (pulse amplitude of $-50 \mathrm{mV}$ and a pulse duration of $40 \mathrm{~ms}$ ) without using a previous adsorptive deposition step at the HMDE.

The linear range for the amfepramone determination by DPV was between 0.05 and $2.0 \mathrm{mg} \mathrm{L}^{-1}$ in acidic medium [peak current at $-0.7 \mathrm{~V}$, with $\mathrm{r}=0.998$ for a linear regression curve $\left.\mathrm{I}(\mathrm{nA})=44.028 \mathrm{c}\left(\mathrm{mg} \mathrm{L}^{-1}\right)+0.1938\right]$ and between 0.25 and $4.0 \mathrm{mg} \mathrm{L}^{-1}$ in alkaline medium [peak current at $-1.65 \mathrm{~V}$, with $\mathrm{r}=0.994$ for a linear regression curve $\left.\mathrm{I}(\mathrm{nA})=5.950 \mathrm{c}\left(\mathrm{mg} \mathrm{L}^{-1}\right)+0.0012\right]$. The linear range in alkaline medium can be extended to $10 \mathrm{mg} \mathrm{L}^{-1}$ $(r=0.997)$ if the measurements are made by differential pulse voltammetry using the static mercury drop electrode (SMDE) as working electrode.

The relative standard deviation calculated was $2.5 \%$ and $4.0 \%$ for five measurements of $500 \mu \mathrm{g} \mathrm{L}^{-1}$ amfepramone in acidic and alkaline medium, respectively. Detection limits of 35.0 and $180.0 \mu \mathrm{g} \mathrm{L}^{-1}$ for the amfepramone determination in acidic and alkaline medium, respectively, were calculated from the $(3 \sigma)$ standard deviation $(n=3)$ of the noise of the equipment and the slope of the calibration function. ${ }^{21}$

\section{Analytical application}

The systematic investigations described above for the acidic and alkaline supporting electrolytes showed to be possible the determination of amfepramone at different peak potentials $(-0.78 \mathrm{~V},-1.35 \mathrm{~V}$, and $-1.70 \mathrm{~V})$, what can be very important for its selective analytical determination in the presence of other pharmaceuticals as interferents.
In order to improve the validation of the methods described above, we have applied them for the amfepramone determination in tablets and capsules of the commercial pharmaceutical formulations Inibex ${ }^{\circledR}$ (Novaquímica), Hipofagin ${ }^{\circledR}$ (Medley) and Dualid ${ }^{\circledR}$ (Ache) containing $75 \mathrm{mg}$ of amfepramone hydrochloride per tablet or capsule. The formulations were analized by the proposed DPV methods using both the acidic and alkaline supporting electrolytes. It is important to highlight that none of the procedures were interfered by the matrices. Additionally, solutions resulting from solubilisation of the tablets and capsules did not need to be filtered exaustively before voltammetric determinations, which can be even performed in the presence of particulate matter. ${ }^{13}$ The voltammograms in Figure 5 show the determination of amfepramone in two pharmaceutical formulations employing the electrolyte systems studied in this work. Five replicate determinations in three different formulations gave average results, which are shown in Table 1. As can be seen, good accuracy was obtained comparing the obtained results with the content declared by the pharmaceutical industries on the drug packaging. Recoveries (\%) in the range 94.7 to 106.6 were obtained for all the formulations with both supporting electrolytes. The Student's $t$-test ${ }^{22}$ was applied in order to compare the mean values (in $\mathrm{mg}$ ) obtained by the proposed methods with that nominal content declared by the manufacturers in each formulation (Table 1). The $t$-test also indicated that there were no systematic errors during execution of the procedures, since the experimental values obtained for $t$ were always lower than the theoretical value ( $t=$ 2.776 for $\mathrm{N}=5){ }^{22}$ The experimental $t$ values obtained with the mean values shown in table 1 are the following: $t=2.023$ (acidic medium) and $t=0.206$ (alkaline medium) for Inibex ${ }^{\oplus} ; t=2.430$ (acidic medium) and $t=2.619$ (alkaline medium) for Hipofagin ${ }^{\circledR} ; t=0.958$ (acidic medium) and $t=0.163$ (alkaline medium) for Dualid ${ }^{\circledR}$.

The determination of amfepramone in the presence of other drugs normally found as adulterants in so-called "natural" formulations used in the treatment of obesity was also investigated. These formulations may contain undeclared drugs, which can produce severe side

Table 1. Results from determination of amfepramone in commercial tablets and capsules $(n=5)$ by differential pulse voltammetry (DPV)

\begin{tabular}{lccr}
\hline Commercial name & Content declared $/(\mathrm{mg})^{\mathrm{a}}$ & $\begin{array}{c}\text { Content determined } /(\mathrm{mg})^{\mathrm{a}} \\
\text { DPV in acidic medium }\end{array}$ & DP in alkaline medium $^{\mathrm{c}}$ \\
\hline Inibex $^{\circledR}$ & 75.0 & $71.2 \pm 5.2$ & $74.4 \pm 8.0$ \\
Hipofagin $^{\circledR}$ & 75.0 & $80.0 \pm 5.7$ & $79.1 \pm 4.3$ \\
Dualid $^{\circledR}$ & 75.0 & $76.2 \pm 3.5$ & $75.4 \pm 6.8$ \\
\hline
\end{tabular}

${ }^{\mathrm{a}} \mathrm{mg} /$ tablet or $\mathrm{mg} / \mathrm{capsule}$ (true mean values calculated by the Student's $t$-test considering $\mathrm{N}=5$ ); ${ }^{\mathrm{b}}$ Supporting electrolyte: $\mathrm{H}_{2} \mathrm{SO}_{4} 0.1 \mathrm{~mol} \mathrm{~L}^{-1}$; ${ }^{\mathrm{C}} \mathrm{Supporting}$ electrolyte: Ringer buffer $\mathrm{pH} 11.0\left(\mathrm{Na}_{2} \mathrm{HPO}_{4} 0.5 \mathrm{~mol} \mathrm{~L}^{-1} / \mathrm{NaH}_{2} \mathrm{PO}_{4} 0.5 \mathrm{~mol} \mathrm{~L}^{-1}\right)$. 

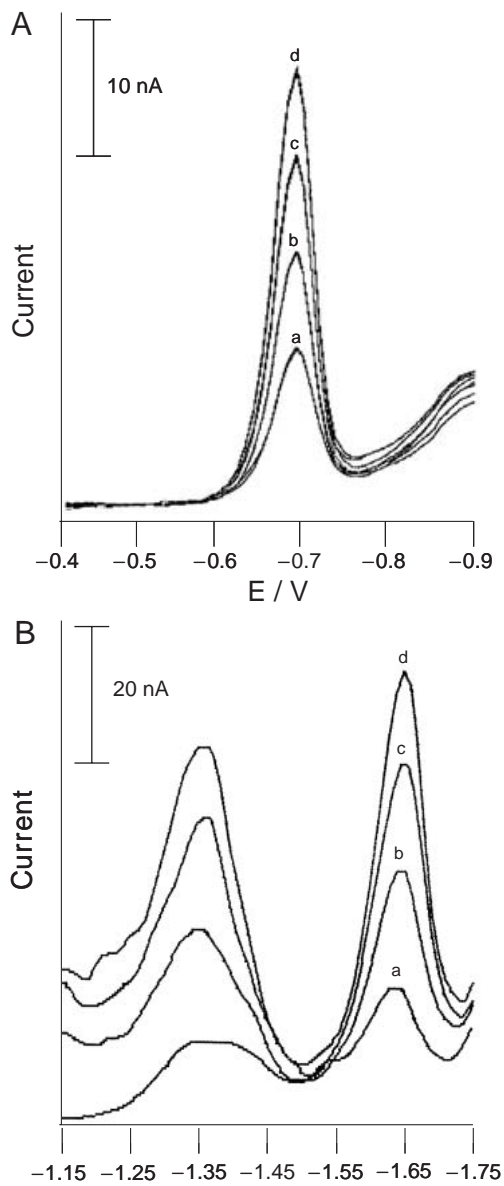

$\mathrm{E} / \mathrm{V}$

Figure 5. Determination of amfepramone by DPV in commercial formulations of amfepramone hydrochloride by the standard addition method $(n=3)$ using (A) $\mathrm{H}_{2} \mathrm{SO}_{4} 0.1 \mathrm{~mol} \mathrm{~L}^{-1}$ and (B) Ringer buffer $\left(\mathrm{Na}_{2} \mathrm{HPO}_{4} 0.5\right.$ mol L-1/ $\mathrm{NaH}_{2} \mathrm{PO}_{4} 0.5 \mathrm{~mol} \mathrm{~L}^{-1}$ ) as supporting electrolyte. (A): (a) sample of Hipofagin ${ }^{\circledR}(100 \mu \mathrm{L}$ of extract as described in section 2.3.2), (b) sample + $0.2 \mathrm{mg} \mathrm{L}^{-1}$ amfepramone, (c) sample + $0.4 \mathrm{mg} \mathrm{L}^{-1}$ amfepramone, (d) sample $+0.6 \mathrm{mg} \mathrm{L}^{-1}$ amfepramone. (B): (a) sample of Dualid ${ }^{\circledR}(100 \mu \mathrm{L}$ of extract as described in section 2.3.2), (b) sample $+0.75 \mathrm{mg} \mathrm{L}^{-1}$ amfepramone, (c) sample $+1.5 \mathrm{mg} \mathrm{L}^{-1}$ amfepramone, (d) sample +2.25 $\mathrm{mg} \mathrm{L}^{-1}$ amfepramone. The scan rate was $20 \mathrm{mV} \mathrm{s}^{-1}$ (A and $\left.\mathrm{B}\right)$. effects. Among these adulterants the most probable are anorexics, tranquilizers, antidepressants and hypoglicemics. The presence of amfepramone in herbal formulations commercialized in Brazil has already been described in literature. ${ }^{23}$ In view of a growing interest on this specific problem around the world, we have applied the proposed methods for the anfepramone determination in the presence of some adulterants already reported in addulteration cases of natural formulations..$^{9,23-29}$ Table 2 shows recovery values for amfepramone in synthetic mixtures containing the adulterants fenproporex, mazindol, sibutramine, fluoxetine, caffeine, diazepam, and metformin. Recoveries (\%) in the range 90.0 to 101.0 for amfepramone obtained in synthetic mixtures prove the satisfactory accuracy and applicability of the proposed method for the amfepramone determination in the presence of other adulterants, which may be present in pharmaceutical formulations commercialized as natural medicaments. Furthermore, the drugs tested in the mixture did not interfere on the determination of amfepramone either in acidic or in alkaline medium. However, it was observed that mazindol has a voltammetric signal close to that of amfepramone in acidic medium, what might lead to a false positive result for amfepramone in this supporting electrolyte. In fact, the voltammetric signal of mazindol is lesser sensitive than the signal of amfepramone in this medium and it does not represent a serious interference, as proved by the recovery results obtained by the standard addition method (Table 2). Besides these results, we suggest the determination of amfepramone in the presence of other drugs as adulterants to be made in alkaline medium (Ringer buffer at $\mathrm{pH} 11.0$ ) with the measurement of peak current at $-1.65 \mathrm{~V}$, in which peak potential the

Table 2. Recovery experiments for amfepramone $(n=3)$ in synthetic mixtures containing other drugs as adulterants

\begin{tabular}{lcl}
\hline Amfepramone added / $\left(\mathrm{mg} \mathrm{L}^{-1}\right)$ & $\begin{array}{c}\text { Concentration of each drug } \\
\text { in the synthetic mixture } /\left(\mathrm{mg} \mathrm{L}^{-1}\right)^{\mathrm{a}}\end{array}$ & Recovery $(\%)$ \\
\hline 0.1 & 0.1 & $90.0^{\mathrm{a}} \pm 2^{\mathrm{b}}$ \\
& 0.2 & $98.0 \pm 1^{\mathrm{b}}$ \\
0.5 & 0.5 & $99.0 \pm 1^{\mathrm{b}}$ \\
& 0.1 & $96.0 \pm 2^{\mathrm{b}}$ \\
1.0 & 0.2 & $90.0 \pm 2^{\mathrm{b}}$ \\
& 0.5 & $94.0 \pm 2^{\mathrm{b}}$ \\
2.0 & 0.5 & $98.0 \pm 3^{\mathrm{c}}$ \\
& 1.0 & $90.0 \pm 2^{\mathrm{c}}$ \\
& 2.0 & $101.0 \pm 2^{\mathrm{c}}$ \\
& 0.5 & $97.5 \pm 2^{\mathrm{c}}$ \\
\hline
\end{tabular}

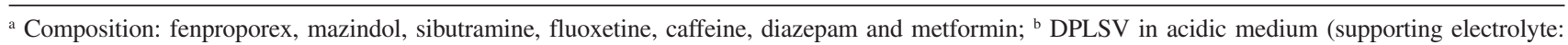
$\mathrm{H}_{2} \mathrm{SO}_{4} 0.1 \mathrm{~mol} \mathrm{~L}^{-1}$ ); ${ }^{\mathrm{c}}$ DPLSV in alkaline medium (supporting electrolyte: Ringer buffer $\mathrm{pH} 9.0-\mathrm{Na}_{2} \mathrm{HPO}_{4} 0.5 \mathrm{~mol} \mathrm{~L}^{-1} / \mathrm{NaH}_{2} \mathrm{PO}_{4} 0.5 \mathrm{~mol} \mathrm{~L}^{-1}$ ). 
other drugs did not present any voltammetric signal. It has been found to be the most selective method for the amfepramone determination, mainly if it is present in a pharmaceutical formulation containing other drugs as adulterants.

\section{Conclusions}

The described methods provide a sensitive determination of amfepramone in tablets and capsules of pharmaceutical formulations by DPV. The determination of amfepramone in these formulations was possible employing both alkaline and acidic electrolyte systems and a simple solubilization of the sample in methanol followed by filtration through cotton as a pretreatment step. The methods allowed also the selective determination of amfepramone in synthetic mixtures containing some anorexics, benzodiazepines, stimulants and antidepressants as adulterants. Recovery experiments for amfepramone in synthetic mixtures containing fenproporex, mazindol, sibutramine, fluoxetine, caffeine, diazepam, and metformin as adulterants confirmed the satisfactory accuracy of the methods. The DPV method using a Ringer buffer $(\mathrm{pH}$ 11.0) as supporting electrolyte seemed also to be useful for the selective determination of amfepramone in formulations commercialized all over the world as natural medicines, in which different classes of drugs can be present as adulterants. The detection limit of $0.18 \mathrm{mg} \mathrm{L}^{-1}$ obtained for amfepramone in this supporting electrolyte allows its sensitive determination as adulterant in formulations, which may contain the drug at therapeutical doses (25 to $75 \mathrm{mg}$ ) and even at low doses.

\section{Acknowledgments}

The authors wish to acknowledge fellowships awarded by the Brazilian foundations CAPES and CNPq. The authors also express their grateful thanks to Metrohm AG Company (Herisau, Switzerland) for the financial support of this work.

\section{References}

1. Nappo, S. A.; Carlini, E. A.; Medicamentos, Drogas e Saúde, Hucitec: São Paulo, 1995.

2. Weiser, M.; Frishman, W. H.; Michaelson, M. D.; Abdeen, M. A.; J. Clin. Pharmacol. 1997, 37, 453.
3. Mello Jr., E. L.; Maiora, R. S.; Careyc, R. J.; Hustonb, J. P.; Tomaza, C.; Muller, C. P.; Eur. J. Pharmacol. 2005, 511, 43.

4. Jasinski, D. R.; Nutt, J. G.; Griffith, J. D.; Clin. Pharmacol. Ther. 1974, 16, 645.

5. Khan, S. A.; Spiegel, D. A.; Jobe, P. C.; Am. Farm. Phys. 1987, 36, 107.

6. Carney, M. W.; Brit. J. Psychiatr. 1988, 152, 146.

7. Brooke, D.; Kerwin, R.; Lloyd, K.; Brit. J. Psychiatr. 1988, 152, 572 .

8. Marquardt, H.; Schäfer, S.; Lehrbuch der Toxikologie, Wissenschaftliche Verlagsgesellschaft: Stuttgart, 2004.

9. Parodi, B.; Caviglioli, G.; Bachi, V.; Cafaggi, S.; Romussi, G.; Pharmazie 1993, 48, 678.

10. Almeida, A. E.; Ribeiro, M. L.; J. Liq. Chromatogr. Rel. Technol. 1999, 22, 1759.

11. Farina, A. M.; Iorio, M. A.; Doldo, A.; Spectrosc. Lett. 1988, $21,455$.

12. Tan, X.; Zhang, S.; Li, Q.; Ниахие Yanjiu Yu Yingyong 1996, 8, 279.

13. dos Santos, M. M. C.; Famila, V.; Gonçalves, M. L. S.; Anal. Bioanal. Chem. 2002, 374, 1074.

14. Bond, A. M.; Modern Polarographic Methods in Analytical Chemistry, Marcel Dekker: New York, 1980.

15. Bard, A. J., Faulkner, L. R.; Electrochemical Methods: Fundamentals And Applications, second edition, John Wiley \& Sons Inc.: New York, 2001.

16. Carvalho, L. M.; Schwedt, G.; Electroanalysis 2001, 13, 596.

17. Sander, S.; Henze, G.; Electroanalysis 1997, 9, 243.

18. Bersier, P. M.; Bersier, J.; CRC Crit. Anal. Chem. 1985, 16, 81.

19. Bersier, P. M.; J. Pharm. Biomed. Analysis 1983, 1, 475.

20. Bersier, P. M.; Bersier, J.; Electroanalysis 1994, 6, 171.

21. Hasebe, K.; Osteryoung, J.; Anal. Chem. 1975, 47, 2412.

22. Cienfuegos, F.; Estatística Aplicada ao Laboratório, Editora Interciência: Rio de Janeiro, 2005.

23. Almeida, A. E.; Ribeiro, M. L.; Polese, L.; J. Liq. Chromatogr. Rel. Technol. 2000, 23, 1109.

24. Keller, T.; Mutz, M.; Aderjan, R.; Latscha, H. P.; Fresenius J. Anal. Chem. 1999, 363, 270.

25. Auricchio, M. T.; Batistic, M. A.; Markman, B. E. O.; Rev. Inst. Adolfo Lutz 1991, 51, 105.

26. Cunha, L. C.; Azeredo, F. S.; Guimarães, R. I.; Paula, J. R.; Rev. Bras. Toxicol. 2002, 15, 69.

27. Kee, S.-K.; Chu, S.-S.; Xu, Y.-M.; Choo, P.-L.; Health Policy 2005, 71, 133.

28. Ernst, E.; J. Intern. Med. 2002, 252, 107.

29. Mikami, E.; Goto, T.; Ohno, T.; Oka, H.; Kanamori, H.; J. Health Sci. 2005, 51, 278.

Received: October 19, 2006 Web Release Date: July 11, 2007 